Ni Made Ayu Aprinia Dewi, I Wayan Wenagama. Faktor-faktor Yang Berpengaruh Terhadap..... 252

\title{
FAKTOR-FAKTOR YANG BERPENGARUH TERHADAP PENDAPATAN USAHA DAGANG PELINGGIH DI KECAMATAN MENGWI
}

\author{
Ni Made Ayu Aprinia Dewi ${ }^{1}$ \\ I Wayan Wenagama ${ }^{2}$
}

${ }^{1,2}$ Fakultas Ekonomi dan Bisnis Universitas Udayana, Bali, Indonesia

e-mail: ayuapriniaa@gmail.com

\begin{abstract}
Factors that Influence Pelinggih Trade Revenue in Mengwi District. Hindus in Bali have a tradition and the thickness of typical rituals such as giving banten. Mengwi Subdistrict as an industrial center has pelinggih trading business as a source of income for the community. This study aims to determine the effect of capital, labor, raw materials and duration of business simultaneously and partially on the income of the trading business in Mengwi District. The data used in this study are primary data, namely by distributing questionnaires to the traders in Mengwi Subdistrict. The population used in this study was all traders in Mengwi Subdistrict. The number of samples used were many as 57 traders, using proportional random sampling sampling techniques. The variables studied in this study are capital, labor, raw materials, length of business and income of pelinggih traders. The analysis technique used in this study is Multiple Linear Regression. Based on the results of the study it was stated that capital, labor, raw materials and duration of business simultaneously had a significant effect on the income of pelinggih trading businesses in Mengwi District. Partially, capital, labor, raw materials and duration of business have a positive and significant effect on the income of the pelinggih trading business in Mengwi District.
\end{abstract}

Keywords: Income; capital; labor; raw materials; length of business.

Abstrak: Faktor-faktor Yang Berpengaruh Terhadap Pendapatan Usaha Dagang Pelinggih di Kecamatan Mengwi. Umat Hindu di Bali memiliki tradisi serta kentalnya ritual-ritual khas seperti menghaturkan banten. Kecamatan Mengwi sebagai sentra industri terdapat usaha dagang pelinggih sebagai salah satu sumber pendapatan masyarakat. Penelitian ini bertujuan untuk mengetahui pengaruh modal, tenaga kerja, bahan baku dan lama usaha secara simultan dan parsial terhadap pendapatan usaha dagang pelinggih di Kecamatan Mengwi. Data yang dipergunakan dalam penelitian ini adalah data primer, yaitu dengan melakukan penyebaran kuisioner kepada para pedagang pelinggih di Kecamatan Mengwi. Populasi yang digunakan dalam penelitian ini adalah seluruh pedagang pelinggih di Kecamatan Mengwi. Jumlah sampel yang digunakan adalah sebanyak 57 pedagang, dengan menggunakan teknik penentuan sampel proportional random sampling. Variabel yang diteliti dalam penelitian ini adalah modal, tenaga kerja, bahan baku, lama usaha dan pendapatan pedagang pelinggih. Teknik analisis yang digunakan dalam penelitian ini adalah Regresi Linier Berganda. Berdasarkan hasil penelitian dinyatakan bahwa modal, tenaga kerja, bahan baku dan lama usaha secara simultan berpengaruh signifikan terhadap pendapatan usaha dagang pelinggih di Kecamatan Mengwi. Secara parsial, modal, tenaga kerja, bahan baku dan lama usaha berpengaruh positif dan signifikan terhadap pendapatan usaha dagang pelinggih di Kecamatan Mengwi.

Kata kunci: Pendapatan modal; tenaga kerja; bahan baku; lama usaha. 


\section{PENDAHULUAN}

Pembangunan pada sektor industri merupakan salah satu cara untuk meningkatkan perekonomian. Ketika perekonomian meningkat, maka kesejahteraan masyarakat yang berdampak pada taraf hidup masyarakat juga akan meningkat. Pembangunan suatu negara bergantung pada perkembangan sektorsektor yang mendukung perekonomian suatu negara. Salah satu sektor yang mempengaruhi kesejahteraan masyarakat adalah sektor ekonomi. Ketimpangan sektor ekonomi menunjukkan bahwa pembangunan suatu negara belum berjalan secara efektif, oleh karena itu keseimbangan antar sektor dapat menopang pembangunan suatu Negara. Menurut Arsyad (2010) dalam Yasa (2015) Tujuan utama dari pembangunan adalah menciptakan kesejahteraan masyarakat dan meningkatkan pertumbuhan ekonomi dan meratanya distribusi pendapatan.

Pembangunan sektor-sektor di Indonesia menjadi prioritas utama yang mendorong kemajuan masyarakat melalui kebijakan pembangunan, salah satu upaya pemerintah adalah pengembangan di sektor industri. Menurut Arsyad (2001) dalam Yuniartini (2013) Pembangunan pada sektor industri merupakan kegiatan yang bertujuan untuk meningkatkan kesejahteraan masyarakat, dengan kata lain mampu meningkatkan taraf hidup yang lebih baik. Proses industrialisasi tidak terlepas untuk dapat meningkatkan produktifitas yang di hasilkan oleh pelaku industri melalui penyerapan tenaga kerja dan kemampuan yang dimiliki sehingga dapat meningkatkan pendapatan masyarakat. Menurut Putong (2000) dalam Heryendi (2013) Pendapatan dapat dihitung melalui tiga pendekatan yaitu pendekatan produksi, pendekatan pendapatan dan pendekatan pengeluaran.

Pertumbuhan sektor ekonomi di Indonesia berkembang pesat, salah satunya pada sektor industtri. Sektor industri mempunyai peran yang signifikan bagi masyarakat, karena sektor ini akan menciptakan lapangan pekerjaan bagi masyarakat yang diharapkan untuk membantu proses industrialisasi juga akan meningkatkan pendapatan masyarakat. Pembangunan di sektor industri diharapkan mampu meningkatkan kualitas sumber daya manusia agar bisa dipakai sebagai kesempatan dalam menghadapi globalisasi serta meningkatkan kualitas produksi.

Perkembangan pada sektor industri akan berdampak terhadap sektor-sektor lain yang diharapkan dapat mendorong terjadinya peningkatan pada segala sektor yang akan berdampak pada pertumbuhan perekonomian. Pembangunan sektor industri dapat menunjang dalam penyelesaian pengentasan kemiskinan, penurunan tingkat pengangguran dan telah memberikan sumbangan bagi Produk Domestik Bruto (Ningsih dan Indrajaya, 2015). Sektor industri kecil menengah memiliki kontribusi dalam peningkatan pendapatan nasional, penyerapan tenaga kerja, peningkatan pendapatan bagi masyarakat yang memiliki pendapatan rendah serta dapat memanfaatkan kemampuan menggunakan bahan baku lokal agar menghasilkan barang dan jasa untuk masyarakat luas (Putri dan Jember, 2016)

Bali adalah pulau yang berada di wilayah Indonesia dan menjadi destinasi wisata yang paling diminati oleh wisatawan domestik maupun wisatawan mancanegara. Luas wilayah secara keseluruhan mencapai $5.636,66 \mathrm{~km}^{2}$ atau 0,29 persen dari luas kepulauan Indonesia (BPS, 2016). Pembangunan sektor industri dengan melakukan pengelompokan suatu perusahaan dapat memberikan dampak pada efisiensi dan pertumbuhan produktivitas (Widodo, 2014). Pembangunan industri merupakan suatu kegiatan yang mempunyai potensi untuk dikembangkan mengingat sumber daya alam dan kreativitas masyarakat pada bidang seni dan kerajinan cukup memberikan kontribusi pada peningkatan kesejahteraan masyarakat untuk 
lebih maju dan bermutu (Budiartha, 2013). Provinsi Bali dikenal dengan sebutan Pulau Dewata karena mayoritas penduduk adalah umat Hindu yang menjunjung budaya dan adat istiadat serta menghaturkan persembahan kepada para dewa yang menjaga keselamatan alam semesta beserta isinya. Masyarakat bali dikenal memiliki sikap ramah dan mempunyai budaya yang kental.

Rahmawati (2004) menyatakan penduduk Bali yang mayoritas adala5h beragama Hindu sangat bangga dengan masih adanya tradisi-tradisi serta kentalnya ritualritual khas mereka di tengah-tengah kemajuan zaman terlebih pengaruh luar yang di bawa oleh wisatawan. Bali juga dikenal sebagai daerah tujuan wisata budaya dan spiritual, karena para penghuninya (terutama agama Hindu) selalu melakukan ritual keagamaan. Dalam ritual semacam itu, ada banten atau persembahan kepada Tuhan. Bentuk dan karakter arsitektur tradisional di Bali berkaitan erat dengan budaya, adat istiadat dan sistem religi masyarakat Bali. Pamerajan kamulan ini dapat ditemui pada bagian hulu dan ada pada setiap pekarangan rumah masyarakat Hindu yang di Bali. Penyerapan tenaga kerja dari adanya industri di Kecamatan Mengwi berdasarkan Tabel 1 menunjukkan bahwa jumlah industri kerajinan di Kecamatan Mengwi mencapai 1.131 unit, yang didominasi oleh Kelurahan Kapal yaitu terdapat 158 unit industry.

Kondisi ini merupakan peluang bagi masyarakat Bali untuk memenuhi kebutuhan masyarakat dengan membuka salah satu bidang usaha. salah satunya di Kecamatan Mengwi yaitu industri pengolahan pelinggih yang disajikan pada tabel 2. Tabel 2 menunjukkan jumlah usaha dagang pelinggih yang terdapat di Kecamatan Mengwi dengan jumlah usaha pelinggih terbanyak pada Kelurahan/Desa Kapal dengan jumlah 55 unit dari 132 unit usaha

Tabel 1.

\section{Jumlah Industri Kerajinan dan Tenaga Kerja per Desa / Kelurahan} di Kecamatan Mengwi Tahun 2017

\begin{tabular}{clcc}
\hline No & Desa/Kelurahan & Industri Kerajinan & Tenaga Kerja \\
\hline 1 & Cemagi & 96 & 228 \\
2 & Munggu & 60 & 135 \\
3 & Pererenan & 20 & 41 \\
4 & Tumbak Bayuh & 10 & 19 \\
5 & Buduk & 25 & 56 \\
6 & Abianbase & 95 & 301 \\
7 & Sempidi & 56 & 104 \\
8 & Sading & 83 & 167 \\
9 & Lukluk & 75 & 134 \\
10 & Kapal & 158 & 398 \\
11 & Kekeran & 7 & 12 \\
12 & Mengwitani & 42 & 168 \\
13 & Mengwi & 123 & 228 \\
14 & Gulingan & 5 & 15 \\
15 & Penarungan & 82 & 202 \\
16 & Baha & 19 & 68 \\
17 & Werdi Bhuana & 12 & 38 \\
18 & Sobangan & 112 & 145 \\
19 & Sembung & 51 & 156 \\
20 & Kuwum & - & - \\
\hline & Kecamatan Mengwi & 1131 & 2615 \\
\hline
\end{tabular}

Sumber: data diolah, 2018 
dagang. Ketika industri pengolahan mengalami kenaikan laju pertumbuhan pada tahun 20152017 industri ini dapat memberikan kontribusi yang cukup besar mampu secara signifikan meningkatkan pendapatan usaha dagang pelinggih dan meningkatkan laju pertumbuhan industri pengolahan pada PDRB Kabupaten Badung.

Salah satu faktor penting dalam usaha perdagangan adalah modal. Modal merupakan faktor pendukung yang penting bagi pedagang untuk keberlangsungan usahanya. Besar kecilnya modal yang dipergunakan dalam usaha tentunya akan berpengaruh terhadap pendapatan yang diperoleh pedagang. Stok modal merupakan salah satu faktor penting dalam menentukan pertumbuhan ekonomi dan pembangunan ekonomi, hal ini karena pembentukan modal dengan penggunaan sumber daya dari kurang produktif ke lebih produktif (Van Der Eng, 2009). Kondisi usaha dagang dapat berjalan dengan baik diperlukan modal dagang yang cukup memadai. Modal yang besar akan memungkinkan jumlah persediaan barang dagang seperti bahan baku yang akan dijual akan semakin banyak. Hal ini mempengaruhi tingkat pendapatan pedagang. Kekurangan modal bagi sebagian pedagang akan sangat membatasi kemampuan mengadakan persediaan barang yang cukup (Sasmita, 2017).

Tabel 2.

Jumlah Pedagang Pelinggih di Masing-masing Desa/Kelurahan Kecamatan Mengwi (Unit) Tahun 2018

\begin{tabular}{llc}
\hline No & \multicolumn{1}{c}{ Desa/Kelurahan } & Jumlah \\
\hline 1 & Cemagi & - \\
2 & Munggu & 6 \\
3 & Pererenan & 2 \\
4 & Tumbak Bayuh & 1 \\
5 & Buduk & 2 \\
6 & Abian Base & 16 \\
7 & Sempidi & 4 \\
8 & Sading & 2 \\
9 & Lukluk & 8 \\
10 & Kapal & 55 \\
11 & Kekeran & 7 \\
12 & Mengwitani & 10 \\
13 & Mengwi & 8 \\
14 & Gulingan & - \\
15 & Penarungan & 3 \\
16 & Baha & - \\
17 & Werdi Bhuana & 5 \\
18 & Sobangan & 2 \\
19 & Sembung & 1 \\
20 & Kuwum & - \\
\hline & Kecamatan Mengwi & 132 \\
\hline
\end{tabular}

Sumber: data diolah, 2018 
Tenaga kerja merupakan faktor yang sangat penting dalam sebuah produksi. Tenaga kerja merupakan faktor penggerak faktor input lainnya, tanpa adanya tenaga kerja maka faktor produksi lain tidak akan berarti. Dengan meningkatnya produktifitas tenaga kerja maka akan mendorong peningkatan produksi sehingga pendapatan akan meningkat. Menurut Menurut Sumarsono (2013) apabila banyak produk yang terjual maka pengusaha akan meningkatkan jumlah produksinya. Meningkatkan jumlah produksi akan meningkatnya tenaga kerja yang dibutuhkan, sehingga dengan demikian pendapatan juga akan meningkat.

Menurut Firdausa (2012) faktor penting lainnya dalam menjalani usaha adalah lama usaha. Lama usaha merupakan lama waktu yang sudah dijalani pedagang dalam menjalankan usahanya ini dapat mempengaruhi tingkat pendapatan. Asumsi dasar yang digunakan adalah semakin lama usaha seseorang akan semakin tinggi pula produktivitas kerja seseorang. Lama usaha dengan sendirinya akan meningkatkan pengetahuan dan keterampilan. Semakin lama usaha yang dijalankan, maka pengalaman kerja semakin bertambah dalam menciptakan barang-barang. Semakin lama dan semakin intensif pengalaman kerja akan semakin besar peningkatan tersebut, inilah yang memungkinkan orang bisa menghasilkan barang dan jasa yang makin banyak, beragam dan bermutu.

Lama usaha merupakan suatu penentu dari pendapatan, lama usaha sendiri memiliki pengaruh positif terhadap pendapatan. Hal ini juga didukung dengan hasil penelitian yang berjudul Pengaruh Modal, Tenaga Kerja, dan Lama Usaha Terhadap Pendapatan Pengrajin Industri Kerajinan Anyaman di Desa Bona Kecamatan Blahbatuh Kabupaten Gianyar (Wulandari dan Darsana, 2017). Lama usaha adalah waktu yang sudah dijalani pengusaha dalam menjalankan usahanya. Lama usaha identik dengan pengalaman, semakin lama usaha maka akan semakin baik kualitas usaha tersebut (Asmie, 2008). Semakin lama pedagang menjalani usahanya, maka semakin banyak pengalaman yang didapatkan dan akan semakin banyak pula pendapatan yang diperoleh.

Tenaga kerja merupakan faktor yang sangat penting dalam produksi. Tenaga kerja merupakan faktor penggerak faktor input yang lain, tanpa adanya tenaga kerja maka faktor produksi lain tidak akan berarti. Peningkatan terhadap produktivitas tenaga kerja akan menambah jumlah hasil produksi sehingga pendapatan akan ikut meningkat. Menurut Sundrum (2012), peluang untuk pekerjaan yang lebih produktif, baik juga dapat diperoleh dari kesengajaan kebijakan pemerintah atau kekuatan pasar. Menurut Sumarsono (2013) apabila banyak produk yang terjual dengan demikian pengusaha akan meningkatkan jumlah produksinya. Dengan meningkatnya jumlah produksi maka akan mengakibatkan meningkatnya tenaga kerja yang dibutuhkan, sehingga akan meningkatkan pendapatan. Hasil penelitian yang dilakukan oleh Wirawan dan Indrajaya (2019) memperoleh hasil bahwa tenaga kerja berpengaruh positif terhadap pendapatan.

Umat Hindu memiliki kegiatan adat dan agama yang beragam serta terikat oleh banjar, merajan, dan sebagainya. Perempuan Bali memiliki kewajiban membuat banten, namun tidak menutup kemungkinan kaum laki-laki atau suami membantu mengerjakan tugas tersebut, sehingga terdapat peran aktif perempuan maupun laki-laki dalam kegiatan adat dan agama, selain rutinitas melaksanakan pekerjaan. Apabila seorang memilih mengikuti kegiatan adat dan agama, maka ia harus mengorbankan pekerjaan sehingga tidak bekerja pada hari tersebut dan bisa saja memakan waktu yang sangat lama untuk kembali bekerja. Budaya Bali yang beragam dan mengutamakan kebersamaan masih sangat kental di dalam kehidupan yang dijunjung tinggi oleh umat Hindu dan pelinggih merupakan wadah untuk melakukan persembahyang bagi umat Hindu. 
Tujuan penelitian yang hendak dicapai adalah: 1. Untuk menganalisis dan mengetahui besar pengaruh modal, tenaga kerja, bahan baku dan lama usaha secara parsial terhadap pendapatan usaha dagang pelinggih di Kecamatan Mengwi. 2. Untuk menganalisis dan mengetahui besar pengaruh modal, tenaga kerja, bahan baku dan lama usaha secara simultan terhadap pendapatan usaha dagang pelinggih di Kecamatan Mengwi.

\section{METODE PENELITIAN}

Desain penelitian yang digunakan dalam penelitian ini adalah rancangan penelitian kuantitatif. Rancangan penelitian kuantitatif disebut juga sebagai penelitian yang menggunakan paradigma positivism yaitu dari teori-teori dan temuan orang lain kemudian disusun hipotesis sesuai masalah penelitian yang akan dipecahkan (Sugiono, 2014:13). Lokasi penelitian ini adalah di Kecamatan Mengwi, Kabupaten Badung. Ruang lingkup penelitian ini dilaksanakan dengan memusatkan pembahasan mengenai pendapatan usaha dagang pelinggih dan faktor-faktor yang mempengaruhinya.

Objek penelitian ini adalah modal, tenaga kerja, bahan baku, lama usaha dan pendapatan usaha dagang pelinggih di Kecamatan Mengwi. Jenis data berdasarkan sifatnya yang digunakan dalam penelitian ini adalah kuantitatif dan kualitatif. Data kualitatif adalah data yang berupa kata, kalimat, gerak tubuh, ekspresi wajah, bagan, gambar, dan foto yang memberi makna terhadap, fakta-fakta yang diperoleh di tempat penelitian. Sedangkan data kuantitaif dalam penelitian ini yaitu daftar pertanyaan yang terdapat di kuisioner penelitian mengenai modal, produksi, bahan baku dan lama usaha di Kecamatan Mengwi. Sumber data yang digunakan adalah sumber data primer dan data sekunder. Data primer dalam penelitian ini diperoleh melalui penyebaran kuisioner dengan mencantumkan daftar pertanyaan yang telah disiapkan terlebih dahulu. Daftar pertanyaan tersebut menyangkut tentang modal, tenaga kerja, bahan baku, lama usaha, pendapatan usaha dagang pelinggih di Kecamatan Mengwi. Sedangkan data sekunder yang digunakan dalam penelitian ini diperoleh dari Badan Pusat Statistik, Dinas Perdagangan dan Perindustrian Kabupaten Badung.

Populasi dalam penelitian ini adalah usaha dagang pelinggih di Kecamatan Mengwi dengan jumlah sebanyak 132 unit. Sampel yang digunakan dalam penelitian ini adalah usaha dagang pelinggih di Kecamatan Mengwi. Jumlah sampel yang digunakan dalam penelitian ini ditentukan berdasarkan pendekatan Slovin, yang menggunakan rumus sebagai berikut (Sugiyono, 2015):

$$
n=\frac{\mathrm{N}}{1+\mathrm{Ne}^{2}}
$$

Keterangan:

$$
\begin{aligned}
& \mathrm{n} \text { : Ukuran sampel } \\
& \mathrm{N}: \text { Ukuran populasi } \\
& \text { e : Nilai Kritis }(10 \%)
\end{aligned}
$$

Berdasarkan jumlah usaha dagang pelinggih di Kecamatan Mengwi sebanyak 132 usaha dagang, maka perhitungan sampel dalam penelitian ini adalah:

$$
\begin{aligned}
& n=\frac{132}{1+\left(132 \times 0,1^{2}\right)} \\
& n=56,89 \text { dibulatkan menjadi } 57
\end{aligned}
$$

Pengambilan jumlah sampel penelitian di masing-masing desa/kelurahan ditentukan dengan menggunakan metode proportional random sampling. perhitungan jumlah usaha dagang pelinggih di masing-masing desa/ kelurahan.

Metode pengumpulan data yang digunakan adalah observasi terstruktur dan wawancara. Observasi terstruktur adalah observasi yang telah dirancang secara sistematis serta telah diketahui tentang tempat dan variabel yang diteliti sedangkan wawancara merupakan pengumpulan data yang dilakukan melalui tatap muka langsung dengan responden, dengan berpedoman pada daftar pertanyaan yang 
terstruktur yang digunakan untuk memperoleh informasi Dimana untuk menganalisis data, digunakan teknik analisis Regresi Linear Berganda dengan menggunakan program SPSS. Persamaan dapat dinyatakan sebagai berikut:

$$
Y=\beta 0+\beta_{1} X_{1}+\beta_{2} X_{2}+\beta_{3} X_{3}+\beta_{4} X_{4}+\mu i
$$

Keterangan :

$$
\begin{aligned}
& Y=\text { Pendapatan Pedagang (Rupiah) } \\
& \beta_{0}=\text { Konstanta } \\
& X_{1}=\text { Modal } \\
& X_{2}=\text { Tenaga Kerja } \\
& X_{3}=\text { Bahan Baku } \\
& X_{4}=\text { Lama Usaha }
\end{aligned}
$$

$\beta_{1} \beta_{2} \beta_{3} \beta_{4}=$ Koefisien Regresi masing masing variabel independen.

$$
\mu i=\text { error }
$$

Secara sistematis, desain penelitian ini dapat dilihat pada Gambar 1.

Variabel modal masuk ke dalam variabel bebas pada penilitian ini karena secara teoritis mempengaruhi pendapatan. Modal merupakan faktor penting dalam melakukan usaha, sebab modal memiliki hubungan yang sangat kuat atas berhasil atau gagalnya suatu usaha yang dijalankan. Hasil penelitian Priyandika (2015), menyatakan bahwa modal berpengaruh positif dan signifikan terhadap pendapatan. Hal ini juga sejalan dengan hasil penelitian Adhiatma (2014), yang menyatakan bahwa modal secara parsial memiliki pengaruh yang signifikan terhadap pendapatan pedagang. Ini mengidentifikasikan bahwa semakin besar modal yang digunakan pedagang maka akan semakin tinggi pendapatan yang diperoleh pedagang.

Variabel tenaga kerja masuk ke dalam variabel bebas pada penelitan ini. Tenaga kerja merupakan faktor yang sangat penting dalam produksi, karena tenaga kerja merupakan faktor penggerak faktor input lain, tanpa adanya tenaga kerja maka faktor produksi lain tidak akan berarti. Dengan meningkatkan produktivitas tenaga kerja akan mendorong peningkatan produksi sehingga pendapatan akan meningkat. Menurut

Gambar 1.

\section{Kerangka Konseptual Penelitian}

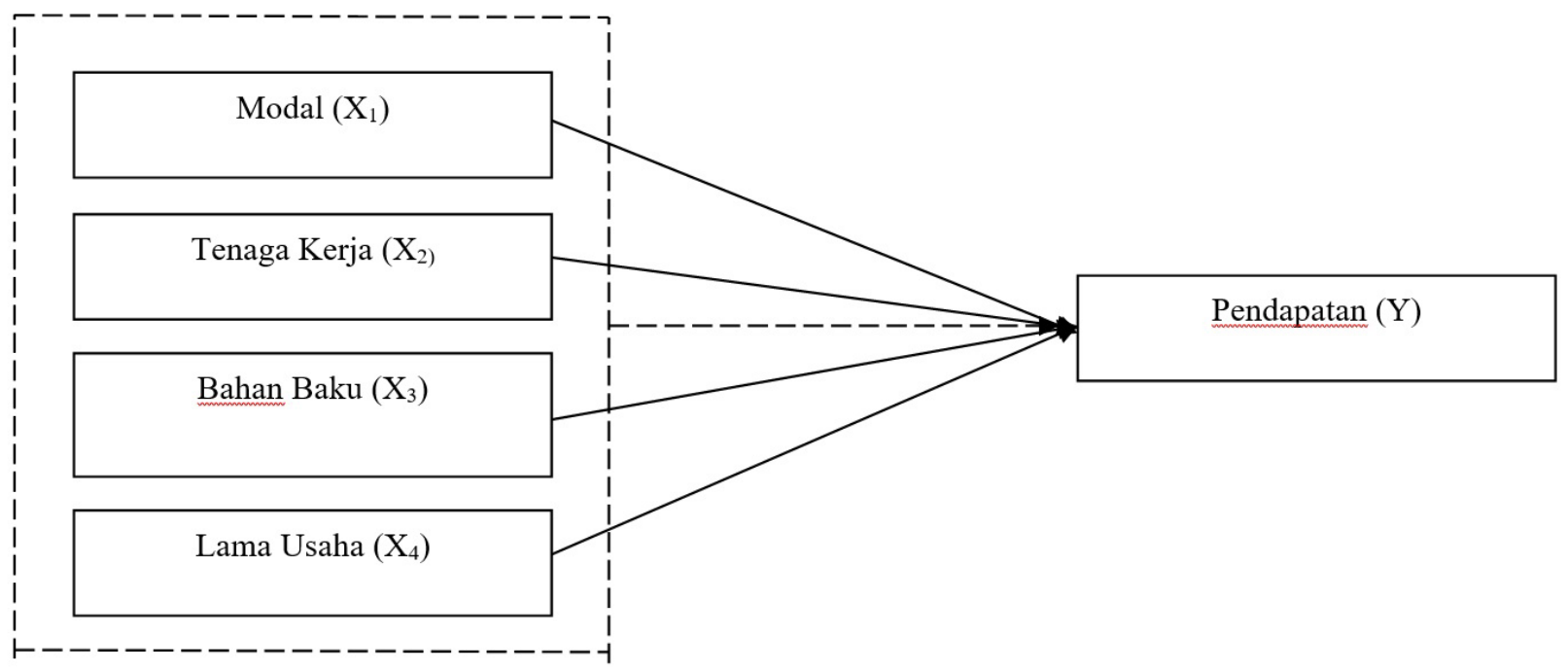

Keterangan: $\longrightarrow$ Pengaruh parsial $\mathrm{X}_{1}$ dan $\mathrm{X}_{2}, \mathrm{X}_{3}$ terhadap $\mathrm{Y}$

$\cdots$ Pengaruh simultan $\mathrm{X}_{1}, \mathrm{X}_{2}, \mathrm{X}_{3}$ terhadap $\mathrm{Y}$ 
Cameron et all., (2018) salah satu faktor yang mempengaruhi seseorang bekerja adalah tingkat pendidikan, semakin banyak pekerja akan meningkatkan kesejahteraan, kualitas individu serta pertumbuhan ekonomi di wilayah tersebut dapat dilihat melalui PDRB. Nata dan Wirathi (2017) dalam penelitiannya memperoleh hasil bahwa tenaga kerja berpengaruh positif secara parsial terhadap pendapatan perajin genteng. Hal ini juga serupa dengan penelitian yang dilakukan Mahayasa dan Yuliarmi (2017) dalam penelitiannya memperoleh hasil tenaga kerja berpengaruh positif dan signifikan terhadap pendapatan usaha kerajinan ukiran kayu di Kecamatan Tembuku Kabupaten Bangli. Apabila tenaga kerja mengalami peningkatan produktivitas maka dapat memenuhi permintaan konsumen sehingga dengan demikian pendapatan akan meningkat.

Variabel ketiga yang mempengaruhi pendapatan adalah bahan baku. Semakin besar jumlah bahan baku yang dimiliki, maka semakin besar kemungkinan jumlah produk yang dihasilkan, sehingga besar kemungkinan pendapatan yang diterima semakin besar dari hasil penjualan produksinya. Hasil penelitian yang dilakukan oleh Agustina (2017) menunjukkan secara simultan variabel tenaga kerja, modal dan bahan baku berpengaruh positif dan signifikan terhadap produksi industri kerajinan patung kayu di Kecamatan Tegallalang Kabupaten Gianyar. Secara parsial variabel modal dan bahan baku berpengaruh positif dan signifikan terhadap produksi kerajinan patung kayu di Kecamatan Tegallalang Kabupaten Gianyar.

Variabel keempat yang mempengaruhi pendapatan adalah lama usaha. Pengaruh pengalaman berusaha terhadap tingkat pendapatan telah dibuktikan dalam penelitian Tjiptoroso (1993) lamanya seorang pelaku bisnis menekunibidang usahanyaakan mempengaruhi kemampuan profesionalnya. Menurut Hastina (2013) bahwa semakin lama suatu usaha berdiri maka akan semakin berpengaruh terhadap pendapatan pengusahanya. Semakin lama usahanya berdiri maka semakin banyak orang mengetahui kinerja dari usahanya. Hasil penelitian Wulandari (2017) menunjukkan bahwa lama usaha berpengaruh secara signifikan terhadap pendapatan dengan asumsi variabel konstan pada pengrajin industri kerajinan anyaman di Desa Bona, Kecamatan Blahbatuh, Kabupaten Gianyar.

\section{HASIL DAN PEMBAHASAN}

Berdasarkan hasil penelitian yang dilakukan dapat diketahui bahwa gambaran tentang karakteristik responden. Uraian tentang karakteristik usaha dagang pelinggih responden akan dipaparkan secara mendetail berdasarkan umur, pendidikan, modal, tenaga kerja, bahan baku dan pendapatan sebagai berikut.

Usaha dagang pelinggih di Kecamatan Mengwi yang menjadi objek dalam penelitian ini sebanyak 57 responden. Kelompok responden berdasarkan umur ditunjukkan pada Tabel 3. Tabel 3 menunjukkan bahwa umur dari pemilik usaha dagang pelinggih di Kecamatan Mengwi dengan persentase tertinggi berada diantara umur 41-50 dengan persentase 43,86\% dan persentase terendah pada umur $>60$ yaitu dengan persentase 5,26\%.

Pendidikan merupakan salah satu penentu kualitas dari sumber daya manusia (SDM). Semakin tinggi tingkat pendidikan seseorang, maka semakin tinggi tingkat wawasan dan kualitas yang dimiliki. Pada Tabel 4 dapat dilihat tingkat pendidikan responden usaha dagang pelinggih di Kecamatan Mengwi.

Berdasarkan tabel 4 menunjukkan bahwa jenjang pendidikan pada usaha dagang pelinggih di Kecamatan Mengwi paling banyak adalah lulusan SMA yaitu 28 orang dengan persentase 49,12\% dan paling sedikit yaitu lulusan S1 dengan persentase 10,53\% yaitu 10 orang saja. Rendahnya tingkat pendidikan menjadi kendala dalam menjalani sebuah bisnis.

Pendapatan adalah penghasilan yang diterima oleh seseorang dari usaha atau kegiatan 
Tabel 3.

Distribusi Responden Berdasarkan Umur

\begin{tabular}{cccc}
\hline No & Kelompok Umur (Tahun) & Jumlah responden & Persentase (\%) \\
\hline 1 & $31-40$ & 17 & 29,83 \\
2 & $41-50$ & 25 & 43,86 \\
3 & $51-60$ & 12 & 21,05 \\
4 & $>60$ & 3 & 5,26 \\
\hline & Total & $\mathbf{5 7}$ & $\mathbf{1 0 0}$ \\
\hline
\end{tabular}

Sumber: Data Primer Diolah, 2019

Tabel 4.

Distribusi Responden Berdasarkan Tingkat Pendidikan

\begin{tabular}{cccc}
\hline No & Tingkat Pendidikan & Jumlah responden & Persentase (\%) \\
\hline 1 & SD & 10 & 17,54 \\
2 & SMP & 13 & 22,81 \\
3 & SMA & 28 & 49,12 \\
4 & S1 & 6 & 10,53 \\
\hline & Total & $\mathbf{5 7}$ & $\mathbf{1 0 0}$ \\
\hline
\end{tabular}

Sumber: Data Primer Diolah, 2019

yang dilakukan dalam jangka waktu tertentu yang dapat berupa barang dan jasa. Tabel 5 . berikut memaparkan jumlah responden usaha dagang pelinggih di Kecamatan Mengwi berdasarkan tingkat pendapatan yang diperoleh per tahun.

Tabel 5 menunjukkan bahwa pendapatan yang diperoleh para usaha dagang pelinggih di Kecamatan Mengwi yang paling tinggi mencapai lebih dari $\mathrm{Rp} 100.000 .000$ yaitu sebanyak 25 unit usaha dagang dengan persentase $43,86 \%$. Hal ini menunjukkan bahwa cukup banyak konsumen yang berminat terhadap hasil pelinggih di Kecamatan Mengwi, sehingga para usaha dagang dapat memperoleh pendapatan yang cukup setiap tahunnya.

Modal merupakan faktor pendukung positif dalam pengembangan usaha, semakin besar modal yang ditanamkan dalam suatu usaha maka semakin maksimal output yang dihasilkan, sehingga dapat lebih mengembangkan usaha dalam hal peningkatan pendapatan. Dalam penelitian ini modal dimaksud adalah aset berupa pembelian peralatan produksi dan membiayai perbaikan tersebut untuk menghasilkan suatu barang yaitu pelinggih. Tabel 6 berikut menunjukkan jumlah usaha dagang pelinggih di Kecamatan Mengwi berdasarkan besarnya modal yang digunakan.

Tabel 6 menunjukkan bahwa modal yang digunakan usaha dagang pelinggih di Kecamatan Mengwi tertinggi berada pada nilai Rp. 10.000.000 hingga Rp 20.000.000 yakni sebanyak 32 unit usaha dengan persentase sebesar 56,14\%. Sedangkan pada modal Rp 31.000.000 hingga lebih dari Rp 40.000.000 memiliki persentase yang sama yakni 8,77\%. Modal usaha pada awal pendirian usaha bersumber dari modal pinjaman pada lembaga keuangan dan modal sendiri. Setelah usaha 
Tabel 5.

Disribusi Responden Berdasarkan Pendapatan Pertahun

\begin{tabular}{cccc}
\hline No & Pendapatan (Rupiah) & Jumlah Responden & Persentase (\%) \\
\hline 1 & $<20.000 .000$ & 4 & 7,02 \\
2 & $20.000 .000-50.000 .000$ & 8 & 14,03 \\
3 & $51.000 .000-100.000 .000$ & 20 & 35,09 \\
4 & $>100.000 .000$ & 25 & 43,86 \\
\hline & Total & $\mathbf{5 7}$ & $\mathbf{1 0 0}$ \\
\hline
\end{tabular}

Sumber: Data Primer Diolah, 2019

Tabel 6.

Disribusi Responden Berdasarkan Modal Pertahun

\begin{tabular}{cccc}
\hline No & Pendapatan (Rupiah) & Jumlah responden & Persentase (\%) \\
\hline 1 & $10.000 .000-20.000 .000$ & 32 & 56,14 \\
2 & $21.000 .000-30.000 .000$ & 15 & 26,32 \\
3 & $31.000 .000-40.000 .000$ & 5 & 8,77 \\
4 & $>40.000 .000$ & 5 & 8,77 \\
\hline & Total & $\mathbf{5 7}$ & $\mathbf{1 0 0}$ \\
\hline
\end{tabular}

Sumber: Data Primer Diolah, 2019

berjalan, selanjutnya modal usaha yang digunakan adalah hasil dari produksi usaha tahun sebelumnya.

Tabel 7 menunjukkan bahwa jumlah tenaga kerja yang digunakan dari usaha dagang pelinggih di Kecamatan Mengwi paling banyak yaitu $2-4$ orang dengan persentase 64,91, sedangkan penggunaan tenaga kerja yang paling sedikit hanya pada 5 unit usaha dengan tenaga kerja yang digunakan sebanyak lebih dari 8 orang dengan persentase 8,77 persen. Hal ini menunjukkan bahwa dalam menjalankan usahanya, para unit usaha dagang tersebut hanya menggunakan beberapa tenaga kerja sehingga dapat mendukung berjalannya usaha ini.

Bahan baku juga merupakan faktor penting yang dibutuhkan dalam proses produksi sebuah pelinggih. Semakin besar jumlah bahan baku yang dimiliki, maka semakin besar pula kemungkinan jumlah produk yang dihasilkan, sehingga memungkinkan pendapatan yang diterima semakin besar dari hasil penjualan produksinya. Berikut ini jumlah responden usaha dagang pelinggih di Kecamatan Mengwi berdasarkan bahan baku yang dilihat dari nilai bahan bakunya pada Tabel 8 .

Pada Tabel 8 bahan baku terbesar digunakan berada pada nilai $\mathrm{Rp} 5.500 .000$ hingga $\mathrm{Rp} 10.000 .000$ dengan 40 unit usaha dengan tingkat persentase $70,17 \%$, sedangkan yang paling sedikit nilai bahan baku yang digunakan adalah $\leq$ Rp 5.000 .000 yaitu hanya 1 unit saja dengan persentase $1,75 \%$.

Lama usaha merupakan waktu yang sudah dijalani oleh pedagang dalam menjalankan usahanya. Lama usaha identik dengan pengalaman dalam berdagang. Pada Tabel 9 menunjukkan jumlah responden usaha 
Tabel 7.

Distribusi Responden Berdasarkan Tenaga Kerja yang digunakan

\begin{tabular}{cccc}
\hline No & Tenaga Kerja (orang) & Jumlah responden & Persentase (\%) \\
\hline 1 & $2-4$ & 37 & 64,91 \\
2 & $5-8$ & 15 & 26,32 \\
3 & $>8$ & 5 & 8,77 \\
\hline & Total & $\mathbf{5 7}$ & $\mathbf{1 0 0}$ \\
\hline
\end{tabular}

Sumber: Data Primer Diolah, 2019

Tabel 8.

Distribusi Responden Berdasarkan Bahan Baku

\begin{tabular}{cccc}
\hline No & Bahan Baku (Rupiah) & Jumlah responden & Persentase (\%) \\
\hline 1 & $\leq 5.000 .000$ & 1 & 1,75 \\
2 & $5.500 .000-10.000 .000$ & 40 & 70,17 \\
3 & $10.500 .000-15.000 .000$ & 12 & 21,05 \\
4 & $15.500 .000-20.000 .000$ & 4 & 7,03 \\
\hline & Total & $\mathbf{5 7}$ & $\mathbf{1 0 0}$ \\
\hline
\end{tabular}

Sumber: Data Primer Diolah, zUIy

dagang pelinggih di Kecamatan Mengwi berdasarkan lama usaha yang sudah dijalankan:

Tabel 9 menunjukkan bahwa 43,86\% usaha dagang pelinggih telah beroperasi selama 11-20 tahun yaitu sebanyak 25 pedagang. Hal ini berarti bahwa sebagian besar usaha dagang pelinggih di Kecamatan Mengwi merupakan usaha yang sudah lama berdiri.

Analisis ini digunakan untuk mengetahui besarnya pengaruh variabel modal $\left(\mathrm{X}_{1}\right)$, tenaga kerja (X2), bahan baku (X3) dan lama usaha terhadap pendapatan (Y) usaha dagang pelinggih di Kecamatan Mengwi. Setelah melakukan analisis data dengan menggunakan Statistical Product and Service Solution (SPSS), diperoleh hasil sebagai berikut:

$$
\begin{array}{lll}
\hat{Y} & =6,094+0,318 X_{1}+0,693 X_{2}+ \\
& 0,234 X_{3}+0,283 X_{4} \\
\mathrm{~S}_{\mathrm{b}} & =\quad(0,127) \quad(0,199) \\
(0,073) & (0,086) &
\end{array}
$$

$\mathrm{t}=$

$(3,206) \quad(3,286)$

Sig $=(0,002) \quad(0,016) \quad(0,001)$

$(0,002) \quad(0,002)$

$\mathrm{R}^{2}=0,789$

$\mathrm{F}=48,687$

Sig $=0,000$

Sumber: Diolah dari Data Primer, 2019

Dari persamaan tersebut dapat diketahui besarnya pengaruh masing-masing variabel modal $\left(\mathrm{X}_{1}\right)$, tenaga kerja $\left(\mathrm{X}_{2}\right)$, bahan baku $\left(\mathrm{X}_{3}\right)$ dan lama usaha $\left(\mathrm{X}_{4}\right)$ yang berpengaruh terhadap pendapatan $(\mathrm{Y})$ pada usaha dagang pelinggih di Kecamatan Mengwi dengan interpretasi sebagai berikut.

$\beta_{0}=6,094 \quad$ Memiliki arti bahwa pendapatan usaha dagang pelinggih di Kecamatan Mengwi sebesarnya 6,094 juta rupiah dengan asumsi variabel lain dalam hal ini modal 
Tabel 9.

Distribusi Responden Berdasarkan Lama Usaha

\begin{tabular}{cccc}
\hline No & Lama Usaha (Tahun) & Jumlah Responden & Persentase (\%) \\
\hline 1 & $<10$ & 16 & 28,07 \\
2 & $11-20$ & 25 & 43,86 \\
3 & $21-30$ & 12 & 21,05 \\
4 & $>30$ & 4 & 7,02 \\
\hline & Total & $\mathbf{5 7}$ & $\mathbf{1 0 0}$ \\
\hline
\end{tabular}

Sumber: Data Primer Diolah, 2019

$\left(\mathrm{X}_{1}\right)$, produksi $\left(\mathrm{X}_{2}\right)$, bahan baku $\left(\mathrm{X}_{3}\right)$ dan lama usaha $\left(\mathrm{X}_{4}\right)$ dianggap konstan.

$\beta_{1}=0,318 \quad$ Memiliki arti bahwa bila modal $\left(\mathrm{X}_{1}\right)$ naik sebesar 1 juta rupiah, maka akan menyebabkan pendapatan meningkat sebesar 0,318 juta rupiah, dengan asumsi variabel lain konstan.

$\beta_{2}=0,693 \quad$ Memiliki arti bahwa bila tenaga kerja $\left(\mathrm{X}_{2}\right)$ bertambah orang, maka akan menyebabkan peningkatan produksi meningkat yang akan meningkatkan pendapatan sebesar 0,693 juta rupiah, dengan asumsi variabel lain konstan.

$\beta_{3}=0,234 \quad$ Memiliki arti bahwa bila bahan baku $\left(\mathrm{X}_{3}\right)$ naik sebesar 1 juta rupiah, maka akan menyebabkan pendapatan meningkat sebesar 0,234 juta rupiah, dengan asumsi variabel lain konstan.

$\beta_{4}=0,283 \quad$ Memiliki arti bahwa bila lama usaha $\left(\mathrm{X}_{4}\right)$ bertambah 1 tahun, maka akan menyebabkan pendapatan meningkat sebesar 0,283 juta rupiah, dengan asumsi variabel lain konstan.

Dari hasil output SPSS pada model ummary dapat dilihat nila berarti 78,9 persen variasi (naik turunnya pendapatan yang diterima oleh para usaha dagang pelinggih di Kecamatan Mengwi dipengaruhi oleh variasi (naik turunnya) modal, tenaga kerja, bahan baku dan lama usaha sedangkan sebesar 21,1 persen sisanya dipengaruhi oleh variabel lain yang tidak dimasukkan ke dalam model penelitian.

$R$-square sebesar 0,789 atau sebesar 78,9 persen. Hal tersebut

Uji asumsi klasik dilakukan dengan tujuan untuk memastikan hasil yang diperoleh memenuhi asumsi dasar di dalam analisis regresi. Hasil uji asumsi klasik yang dilakukan dalam penelitian ini adalah uji normalitas, uji multikoliniearitas, dan uji heteroskedastisitas. Hasil dari uji asumsi klasik yang diolah dengan bantuan software SPSS 18.0 disajikan sebagai berikut: Uji ini bertujuan untuk mengetahui apakah residual dari model regresi yang dibuat berdistribusi normal atau tidak. Untuk menguji apakah data yang digunakan normal atau tidak dapat dilakukan dengan menggunakan uji Kolmogorov Sminarnov. Apabila koefisien Asymp. Sig. (2-tailed) lebih besar dari 0,05 maka data tersebut dikatakan berdistribusi normal. 
Berdasarkan Tabel 10 dapat dilihat bahwa nilai Kolmogorov Sminarnov (K-S) sebesar 1,266, sedangkan nilai Asymp. Sig (2-tailed) sebesar 0,081 lebih dari $\alpha 0,05$. Oleh karena itu model yang dibuat layak digunakan untuk analisis lebih lanjut.

Uji ini bertujuan untuk menguji apakah pada model regresi ditemukan adanya kolerasi antar variabel bebas. Adanya multikoleniaritas dapat dilihat dari nilai tolerance atau variance inflation faktor (VIF). Jika nilai tolerance lebih dari 10\% atau VIF kurang dari 10, maka dikatakan tidak ada multikoleniaritas.

Berdasarkan tabel 11 dapat dilihat bahwa nilai tolerance dan VIF untuk setiap variabel yakni modal, tenaga kerja, bahan baku, lama usaha memiliki nilai tolerance yang lebih besar dari $10 \%$ dan nilai VIF lebih kecil dari 10 yang berarti model persamaan regresi bebas dari multikoleniaritas. Hal ini menunjukkan bahwa tidak ada gejala multikoleniaritas dari model regresi yang dibuat, sehingga model tersebut layak digunakan untuk memprediksi.

Uji ini bertujuan untuk mengetahui apakah dalam model regresi terjadi

ketidaksamaan varian dari residual satu pengamatan ke pengamatan lain yang dilakukan dengan uji Glejser. Jika tidak ada satupun variabel bebas yang berpengaruh signifikan terhadap nilai absolute residual atau nilai signifikansinya diatas 0,05 maka tidak mengandung gejala heteroskedastisitas.

Pada tabel 12 dapat dilihat bahwa nilai signifikansi dari variabel modal, tenaga kerja, bahan baku dan lama usaha masing-masing memiliki nilai sebesar 0,$091 ; 0,111 ; 0,070$ dan 0,076. Nilai tersebut lebih besar dari 0,05 yang berarti tidak terdapat pengaruh antara variabel bebas terhadap variabel absolute residual. Dengan demikian model yang dibuat tidak mengandung gejala heteroskedastisitas, sehingga layak digunakan untuk memprediksi.

Tabel 10.

Hasil Uji Normalitas

\begin{tabular}{cc}
\hline \hline & Unstandardized Residual \\
\hline $\mathrm{N}$ & 57 \\
Kolmogorov-Smirnov Z & 1.266 \\
Asymp. Sig (2-tailed) & .081 \\
\hline
\end{tabular}

Sumber: Data Primer Diolah, 2019

Tabel 11.

Hasil Uji Multikoleniaritas

\begin{tabular}{|c|c|c|c|c|c|c|c|c|}
\hline \multicolumn{2}{|c|}{ Model } & \multicolumn{2}{|c|}{$\begin{array}{c}\text { Unstandardized } \\
\text { Coefficients }\end{array}$} & \multirow{2}{*}{$\begin{array}{c}\text { Standardized } \\
\text { Coefficients }\end{array}$} & \multirow[b]{2}{*}{$\mathrm{T}$} & \multirow[b]{2}{*}{ Sig. } & \multicolumn{2}{|c|}{ Collinearity Statistics } \\
\hline & & B & Std. Error & & & & Tolerance & VIF \\
\hline \multirow[t]{5}{*}{1} & (Constant) & 6.094 & 1.870 & & 3.259 & .002 & & \\
\hline & Modal & .318 & .127 & .218 & 2.495 & .016 & .530 & 1.888 \\
\hline & $\begin{array}{l}\text { Tenaga } \\
\text { Kerja }\end{array}$ & .693 & .199 & .325 & 3.489 & .001 & .466 & 2.147 \\
\hline & Bahan Baku & .234 & .073 & .241 & 3.206 & .002 & .716 & 1.396 \\
\hline & Lama Usaha & .283 & .086 & .308 & 3.286 & .002 & .462 & 2.164 \\
\hline
\end{tabular}

Sumber: Data Primer Diolah, 2019 
Tabel 12.

Hasil Uji Heteroskedastisitas

\begin{tabular}{llccccc}
\hline Model & & \multicolumn{3}{c}{ Standardized } \\
\multicolumn{1}{c}{} & & \multicolumn{2}{c}{ Unstandardized Coefficients } & Coefficients & & \\
\cline { 3 - 5 } & & $\mathrm{B}$ & Std. Error & Beta & $\mathrm{T}$ & Sig. \\
\hline 1 & (Constant) & -2.086 & 1.003 & & -2.080 & .043 \\
& Modal & .118 & .068 & .292 & 1.723 & .091 \\
& Tenaga Kerja & -.173 & .107 & -.293 & -1.621 & .111 \\
& Bahan Baku & .072 & .039 & .270 & 1.851 & .070 \\
& Lama Usaha & -.084 & .046 & -.329 & -1.810 & .076 \\
\hline
\end{tabular}

Sumber: Data Primer Diolah, 2019

2,55 maka $\mathrm{H}_{0}$ ditolak dan $\mathrm{H}_{1}$ diterima. Hal ini berarti bahwa variabel modal, tenaga kerja, bahan baku dan lama usaha secara simultan berpengaruh signifikan terhadap pendapatan usaha dagang pelinggih di Kecamatan Mengwi.

Berdasarkan nilai $\mathrm{F}_{\text {hitung }}$ yang diperoleh dari hasil regresi dengen program SPSS kemudian dibandingkan dengan $\mathrm{F}_{\text {tabel }}$ dimana nilai $\mathrm{F}_{\text {hitung }}$ yaitu 48,697 lebih besar dari $\mathrm{F}_{\text {tabel }}$ yaitu sebesar

Dari hasil output SPSS pada uji simultan diperoleh hasil bahwa secara simultan variabel modal $\left(\mathrm{X}_{1}\right)$, tenaga kerja $\left(\mathrm{X}_{2}\right)$, bahan baku $\left(\mathrm{X}_{3}\right)$, lama usaha $\left(\mathrm{X}_{4}\right)$ berpengaruh signifikan terhadap pendapatan (Y) usaha dagang pelinggih di Kecamatan Mengwi. Hal ini dibuktikan dari $\mathrm{F}_{\text {hitung }}$ 48,697 lebih besar dari $\mathrm{F}_{\text {tabel }}$ 2,55. Hal ini berarti tinggi rendahnya pendapatan usaha dagang pelinggih di Kecamatan Mengwi dipengaruhi oleh modal, tenaga kerja, bahan baku dan lama usaha.

Uji regresi parsial (uji t) dilakukan untuk menguji pengaruh secara parsial atau masingmasing variabel modal $\left(X_{1}\right)$, tenaga kerja $\left(X_{2}\right)$, bahan baku $\left(\mathrm{X}_{3}\right)$ dan lama usaha $\left(\mathrm{X}_{4}\right)$ terhadap pendapatan (Y) dengan asumsi variabel-variabel bebas yang lain dianggap konstan.

Oleh karena $t_{\text {hitung }}(2,495)>(1,675) t_{\text {tabel }}$, maka $\mathrm{H}_{0}$ ditolak dan $\mathrm{H}_{1}$ diterima dengan tingkat signifikansi $0,016<0,05$. Ini berarti bahwa secara parsial modal berpengaruh positif dan signifikan secara parsial terhadap pendapatan usaha dagang pelinggih di Kecamatan Mengwi.
Koefisien regresi dari pendapatan $\left(\mathrm{X}_{1}\right)$ 2,495 hal ini berarti setiap kenaikan modal 1 juta rupiah, maka diikuti dengan peningkatan jumlah pendapatan sebesar 2,495 juta rupiah pada pendapatan usaha dagang pelinggih di Kecamatan Mengwi dengan asumsi variabel lainnya konstan.

Modal berpengaruh positif dan signifikan terhadap pendapatan sesuai dengan penelitian yang dilakukan oleh Mithaswari dan Wenagama (2018) yang menyatakan modal berpengaruh positif dan signifikan terhadap pendapatan pedagang di Pasar Seni Guwang. Hasil penelitian ini di dukung oleh penelitian yang dilakukan Putra dan Sudirman (2015), disimpulkan bahwa variabel modal mempunyai pengaruh yang signifikan terhadap pendapatan pada usaha sektor informal di Kecamatan Abiansemal Kabupaten Badung. Hasil penelitian ini juga diperkuat berdasarkan wawancara yang dilakukan dengan Wayan Yasa (52) pada tanggal 10 Januari 2019 sebagai berikut:"Modal adalah hal utama dalam menjalankan sebuah usaha. Modal awal yang saya gunakan dari modal sendiri dan pinjaman dari LPD selanjutnya adalah dari hasil tanda jadi sesuai dengan pesananan dari konsumen dan juga modal tersebut diperoleh dari pendapatan sebelumnya"

Dari wawancara dengan salah satu responden tersebut dapat disimpulkan bahwa apabila permintaan dari konsumen banyak akan meningkatkan modal yang tersedia sehingga 
produksi meningkat dan pendapatan pun akan meningkat, sehingga modal dikatakan berpengaruh positif terhadap pendapatan.

Oleh karena $t_{\text {hitung }}(3,489)>(1,675) t_{\text {tabel}}$, maka $\mathrm{H}_{0}$ ditolak dengan tingkat signifikansi $0,001<0,05$. Ini berarti bahwa tenaga kerja berpengaruh positif dan signifikan secara parsial terhadap pendapatan usaha dagang pelinggih di Kecamatan Mengwi.

Hasil penelitian yang dilakukan oleh Wiguna (2016) menyatakan bahwa tenaga kerja berpengaruh positif dan signifikan terhadap pendapatan. Hal ini juga sejalan dengan penelitian Nata (2017) dalam penelitiannya menyatakan bahwa tenaga kerja memiliki pengaruh positif dan signifikan terhadap pendapatan. Sesuai dengan hukum the law of diminishing returns, setiap tambahan pekerja baru akan memberikan output tambahan artinya penggunaan tenaga kerja mempunyai nilai tambah. Hasil penelitian juga diperkuat berdasarkan wawancara yang dilakukan dengan Ketur Rena (49) sebagai berikut:"Tenaga kerja merupakan salah satu hal penting dalam pembuatan pelinggih. Tenaga kerja tentu sangat membantu dalam proses produksi, tanpa tenaga kerja produksi tidak akan bisa terjadi. Jika tenaga kerja yang saya gunakan banyak, maka akan meningkatkan produksi yang otomatis akan meningkatkan pendapatan yang saya peroleh."

Berdasarkan hasil wawancara terhadap responden diketahui bahwa tenaga kerja berpengaruh positif terhadap pendapatan usaha dagang pelinggih di Kecamatan Mengwi, yaitu tenaga kerja sangat diperlukan pada produksi, semakin tinggi produktivitas tentu saja yang akan meningkatkan pendapatan. Hal ini juga sejalan dengan hasil penelitian Putra dan Wenagama (2019) menyatakan bahwa tenaga kerja berpengaruh positif dan signifikan terhadap industri batok kelapa di Kecamatan Tampaksiring Kabupaten Gianyar.

Oleh karena $t_{\text {hitung }}(3,206)>(1,675) t_{\text {tabel}}$, maka $\mathrm{H}_{0}$ ditolak dengan tingkat signifikansi
$0,002<0,05$. Ini berarti bahwa bahan baku berpengaruh signifikan secara parsial terhadap pendapatan usaha dagang pelinggih di Kecamatan Mengwi.

Bahan baku merupakan faktor yang dapat mempengaruhi pendapatan. Semakin besar jumlah bahan baku yang dimiliki, maka semakin besar pula kemungkinan jumlah produk yang dihasilkan, sehingga kemungkinan pendapatan yang diterima semakin besar. Hasil penelitian yang dilakukan oleh Suartawan dan Purbadharmaja (2017) menyatakan bahwa bahan baku merupakan faktor produksi yang dibutuhkan pada sebuah produksi. Persediaan bahan baku di dalam perusahaan merupakan hal yang sangat penting untuk dikendalikan dengan baik, sehingga dapat menghasilkan pendapatan yang optimal. Hal ini juga sejalan dengan penelitian Wijaya (2016) yang menyatakan bahwa adanya hubungan pengaruh positif dan signifikan antara bahan baku terhadap pendapatan industri kerajinan bambu di Kabupaten Bangli.

Oleh karena $t_{\text {hitung }}(3,286)>(1,675) t_{\text {tabel }}$, maka $\mathrm{H}_{0}$ ditolak dengan tingkat signifikansi $0,000<0,05$. Ini berarti bahwa secara parsial lama usaha berpengaruh positif dan signifikan secara parsial terhadap pendapatan usaha dagang pelinggih di Kecamatan Mengwi.

Lama usaha berpengaruh signifikan terhadap pendapatan sesuai dengan penelitian Purnama (2014) bahwa lama usaha berpengaruh signifikan terhadap pendapatan. Hal ini menunjukkan bahwa semakin lama usaha berdiri akan mempengaruhi kemampuan profesionalnya, meningkatkan ketrampilan sehingga akan meningkatkan pengrajin. Hal ini juga sejalan dengan penelitian yang dilakukan oleh Wulandari dan Darsana (2017) yang menyatakan bahwa lama usaha berpengaruh signifikan terhadap pendapatan dengan asumsi variabel lainnya konstan.

Hasil analisis menunjukkan bahwa modal berpengaruh positif dan signnifikan terhadap pendapatan. Hal ini memiliki makna 
bahwa semakin tinggi modal, maka akan meningkatkan pula pendapatan usaha dagang pelinggih di Kecamatan Mengwi. Begitu pula sebaliknya, semakin rendah modal, maka akan semakin rendah pendapatan yang akan diperoleh. Menurut Manurung (2007), dalam membangun sebuah bisnis dibutuhkan modal. Bisnis yang dibangun tidak akan berkembang tanpa didukung dengan modal, dengan adanya modal akan mempengaruhi pendapatan yang diterima. Apabila modal meningkat maka produksi akan meningkat sehingga dapat meningkatkan pendapatan (Fachrizal, 2016).

Tenaga kerja berpengaruh positif dan signifikan terhadap pendapatan. Hal ini memiliki makna bahwa semakin banyak tenaga kerja yang digunakan, maka akan semakin tinggi pendapatan yang dapat diperoleh. Tenaga kerja merupakan faktor penggerak faktor input lain, tanpa adanya tenaga kerja maka faktor produksi lain tidak akan berarti. Dengan meningkatnya produktivitas tenaga kerja akan mendorong peningkatan produksi sehingga pendapatan pun akan ikut meningkat. Apabila tenaga kerja mengalami peningkatan produktivitas maka akan memenuhi permintaan konsumen sehingga dengan demikian pendapatan akan meningkat.

Variabel bahan baku berpengaruh positif dan signifikan terhadap pendapatan. Hal ini memiliki makna bahwa semakin banyak bahan yang disediakan, maka akan semakin tinggi pendapatan yang diperoleh. Bahan baku juga memiliki peran terhadap produksi dan pendapatan. Semakin besar jumlah bahan baku yang dimiliki, maka semakin besar pula kemungkinan jumlah produk yang dihasilkan, sehingga kemungkinan pendapatan yang diterima semakin besar dari hasil penjualan produksinya.

Lama usaha berpengaruh positif dan signifikan terhadap pendapatan usaha dagang pelinggih di Kecamatan Mengwi. Semakin lama usaha berdiri akan dapat mempengaruhi kemampuan professional dan meningkatkan ketrampilan sehingga akan dapat meningkatkan pendapatan. Lama seorang pelaku bisnis menekuni bidang usahanya akan mempengaruhi produktivitasnya (kemampuan keahliannya), sehingga dapat menambah efisiensi dan kemampuan menekan biaya produksi lebih kecil daripada hasil penjualan. Semakin lama menekuni bidang usaha perdagangan akan makin meningkatkan pengetahuan tentang selera ataupun perilaku konsumen.

\section{SIMPULAN DAN SARAN}

Berdasarkan hasil analisis dan pembahasan, maka dapat ditarik beberapa simpulan sebagai berikut; pertama, hasil analisis menunjukkan modal, tenaga kerja, bahan baku dan lama usaha secara simultan berpengaruh signifikan terhadap pendapatan usaha dagang pelinggih di Kecamatan Mengwi; dan kedua, modal, tenaga kerja, bahan baku dan lama usaha secara parsial berpengaruh positif dan signifikan terhadap pendapatan usaha dagang pelinggih di Kecamatan Mengwi, yaitu bahwa semakin besar modal yang dikeluarkan, bahan baku yang dimiliki, tenaga kerja yang cukup dan lama usaha yang dijalankan akan meningkatkan pendapatan.

Berdasarkan kesimpulan tersebut di tersebut, maka peneliti dapat memberikan beberapa saran sebagai berikut: 1) Usaha dagang pelinggih di Kecamatan Mengwi sebaiknya meningkatkan kapasitasnya dengan menambah peralatan dan teknologi terbaru sehingga output yang dihasilkan dapat meningkat dengan menambahkanmodalusaha;2)Unitusahadagang pelinggih di Kecamatan Mengwi sebaiknya memperhatikan ketersediaan bahan baku yang dimiliki sehingga dapat memperlancar proses produksi sehingga nantinya dapat meningkatkan pendapatan; dan 3) Pada peningkatan produksi dibutuhkan bantuan dari Pemerintah Kabupaten Badung dalam hal pelatihan untuk meningkatkan pengetahuan dalam berbisnis dan tenaga kerja dalam hal peningkatan kualitas produk. Dengan semakin berkembangnya 
pasar maka diharapkan agar kualitas produk yang hasilkan dapat menjadi diandalkan dalam sasaran pengembangan produksi.

\section{REFERENSI}

Adhiatma, Alfian Arif. 2015. Pengaruh Modal Awal, Lama Usaha dan Jam Kerja Terhadap Pendapatan Pedagang kayu Glondong di Kelurahan Karang Kebagusan Kabupaten Jepara. Jurnal Universitas Dian Nuswantoro.

Alfroz, Ahmad. 2010. Human Capital and Labor Productivity in Food Industries of Iran. International Journal of Economic Finance. 2 (4)

Agustina, I Made dan I Nengah Kartika. 2017. Pengaruh Modal, Tenaga Kerja, dan Bahan Baku Terhadap Produksi Industri Kerajinan Patung Kayu di Kecamatan Tegallalang. E-Jurnal EP Unud. 6 (7) : 1302-1301.

Amarjit Gill, Nahum Biger, and Neil Mathur. 2010. The Relationship Between Working Capital Management And Profitability: Evidence From The United States. Business and Economics Journal. 10, pp: 1-9.

Ariessi, Nian Elly dan Made Suyana Utama. 2017. Pengaruh Modal, Tenaga Kerja dan Modal Sosial Terhadap Produktivitas Petani di Kecamatan Sukawati Kabupaten Gianyar. Piramida 8 (2) : 97-107

Asghar Afshar Jahanshahi, Khaled Nawaser, Seyed Mohammad Sadeq Khaksar, Amin Reza Kamallan. 2011. The Relationship between Government Policy and the Growth of Entrepreneurship in the Micro, Small and Medium Enterprises of India. Journal of Technology Management and Innovation.

Budhiartha, I Kadek Agus. 2013. Analisis Skala Ekonomis Pada Industri Batu Bata di Desa Tulikup, Gianyar, Bali. Jurnal
Ekonomi Kuantitatif Terapan. 6 (1): 55-61.

Cameron, Lisa, Diana Contreras Suarez \& William Rowell. 2018. Female Labour Force Participation in Indonesia: Why Has It Stalled?. Bulletin of Indonesian Economic Studies. 1-37.

Chaudhary, Asiya, Neshat Anjum and Mohhamed Perjev. 2016. Productivity Analysis of Steel Industry of India Ltd. International Journal of Commerce, Business and Management (IJCBM), 5 (1): 2319-2828

Firdausa, Rosetyadi Artistyan dan Fitrie Arianti. 2012. Pengaruh Modal Awal, Lama Usaha, Dan Jam Kerja Terhadap Pendapatan Pedagang Kios Di Pasar Bintoro Demak. Diponegoro Journal of Economics. 2 (1), 1-6

Gerben G. Meyer , J.C. (Hans) Wortmann \& Nick B. Szirbik (2011) Production monitoring and control with intelligent products, International Journal of Production Research. 49 (5):303-317.

Heryendi, Timotius Wycliffe. 2013. Efektivitas Program Usaha Peningkatan Keluarga Sejahtera (UPPKS) di Kecamatan Denpasar Barat. Jurnal Ekonomi Kuantitatif Terapan. 6 (2) : 75-85

Irawan, Hendra dan AA Ketut Ayuningsasi. 2017. Analisis Variabel yang Mempengaruhi Pendapatan Pedagang Di Pasar Kreneng Kota Denpasar. E-Jurnal EP Unud. 6 (10) : 1952-1982

Mahayasa, Ida Bagus Adi dan Ni Nyoman Yuliarmi. 2017. Pengaruh Modal, Teknologi dan Tenaga Kerja Terhadap Produksi dan Pendapatan Usaha Kerajinan Ukiran Kayu di Kecamatan Tembuku Kabupaten Bangli. E-Jurnal EP Unud. 6 (8), 1510-154

Mithaswari, IdaAyu Dwi dan I Wayan Wenagama. 2018. Analisis Faktor-Faktor Yang Mempengaruhi Pendapatan Pedagang di Pasar Seni Guwang. E-Jurnal EP 
Unud. 7 (2).

Mustika, Dwi Setyadhi. 2013.Analisis Disparitas Pendapatan Pedagang Makanan Gerobak Dorong Antar Kecamatan di Kota Denpasar. Piramida. 9 (2).

Nata, Ni Putu Naomi Puspita, dan I. G. A. P. Wirathi. 2017. Pengaruh Tenaga Kerja, Modal, Bahan Baku, dan Produksi Pada Pendapatan Pengrajin Perak di Desa Kamasan Kabupaten Klungkung. E-Jurnal Ekonomi Pembangunan Unud. 6. (10), 1935.

Ningsih, Ni Made Cahya dan I Gusti Bagus Indrajaya. 2015. Pengaruh Modal dan Tingkat Upah Terhadap Nilai Produksi Serta Penyerapan Tenaga Kerja Pada Industri Kerajinan Perak. Jurnal Ekonomi Kuantitatif Terapan, 8 (1). $1-112$

Ovtchinnikov, Alexei V. 2010. Capital Structure Decisions: Evidence from Deregulated Industries. Journal of Financial Economics. 95, 249-274

Parinduri, Rasyad A. 2014. Family Hardship and The Growth of Micro and Small Firms in Indonesia. Bulletin of Indonesian Economic Studies. 50 (1), 53-73

Prastyo, Didik dan I Nengah Kartika. 2017. Analisis Faktor-Faktor yang Mempengaruhi Produksi Ayam Boiler di Kecamatan Marga, Kabupaten Tabanan. Piramida 8 (2), 77-86

Putra, I Putu Danendra dan I Wayan Sudirman. 2015. Pengaruh Modal dan Tenaga Kerja Terhadap Pendapatan Dengan Lama Usaha Sebagai Variabel Moderating. E-Jurnal EP Unud. 4 (9), 1110-1139

Putra, MadeDwiSuryadidanIWayan Wenagama. 2019. Analisis Skala Ekonomis dan Efisiensi Pada Industri Batok Kelapa di Kecamatan Tampaksiring Kabupaten Gianyar. E-Jurnal EP Unud. 8 (3)

Putri, Ni Made Dwi Maharani dan I Made Jember. 2016. Pengaruh Modal
Sendiri dan Lokasi Usaha Terhadap Pendapatan Usaha Mikro Kecil Menengah (UMKM) di Kabupaten Tabanan (Modal Pinjaman sebagai Variabel Interverning). Jurnal Ekonomi Kuantitatif Terapan, 9 (2). 89-176

Sarah, Xue Dong and Chros Manning. 2017. Labour-Market Development At a Time of Heightend Uncertaininty. Bulletin of Indonesian Economic Studies. 53 (1)

Shinyoung Jeon. 2013. Agricultural Transformation and The Escape From the Middle Income Country Trap: Challenges Facing Small Farmers in Indonesia in a Time of Gree Restructuring. Bulletin of Indonesian Economic Studies. 49 (3) ,383-384

Sugiyono. 2015. Metode Penelitian Tindakan Komperatif. Bandung: Alfabeta

Sumarsono, Sonny. 2013. Ekonomi Sumber Daya Manusia Teori dan Kebijakan Publik. Yogyakarta: Graha Ilmu.

Sundrum R.M., Arndt H.W. (2012). Employment, Unemployment and Under-Employment. Bulletin Of Indonesian Economic Studies. 16 (3)

Wiguna, I Nyoman Gede Tri dan A.A Bagus Putu Widanta. 2016. Pengaruh Modal Usaha dan Tenaga Kerja Terhadap Pendapatan Dengan Kredit Sebagai Variabel Moderasi Pada Pedagang di Pasar Seni Sukawati. E-Jurnal EP Unud. 5 (10), 1168-1187

Wijaya, I B Kresna dan Made Suyana Utama. 2016. Analisis Faktor-Faktor Yang Mempengaruhi Pendapatan Industri Kerajinan Bambu di Kabupaten Bangli. E-Jurnal EP Unud. 5 (4), 434-459

Wirawan, Ngurah Gede Dwiky dan I Gusti Bagus Indrajaya. 2019. Pengaruh Modal dan Tenaga Kerja Terhadap Produksi dan Pendapatan Pada UKM Pie Susu di Denpasar. E-Jurnal EP Unud. 8 (2), 453-485

Wulandari, Anak Agung Ratih dan Ida Bagus 
Darsana. 2017. Pengaruh Modal, Tenaga Kerja dan Lama Usaha Terhadap Pendapatan Pengrajin Industri Kerajinan Anyaman di Desa Bona Kecamatan Blahbatuh Kabupaten Gianyar. E-Jurnal EP Unud. 6 (4), 564596

Yasa, I Komang Oka Artana dan Sudarsana Arka. 2015. Pengaruh Pertumbuhan Ekonomi dan Disparitas Pendapatan Antardaerah Terhadap Kesejahteraan Masyarakat Provinsi Bali. Jurnal Ekonomi Kuantitatif Terapan, 8 (1). 1-112

Yuniartini, Ni Putu Sri. 2013. Pengaruh Modal, Tenaga Kerja dan Teknologi Terhadap Produksi Industri Kerajinan Ukiran Kayu di Kecamatan Ubud. E-Jurnal EP Unud, 2 (2), 95-101s 